\title{
100-lecie lampy rentgenowskiej
}

\author{
100 Year of X-ray tube
}

\section{Streszczenie}

W artykule przestawiono krótki zarys stosowania pierwszych lamp wyładowczych (zwanych też lampami jonowy$\mathrm{mi}$ i/ lub lampami z zimną katodą) stosowanych do wytwarzania promieniowania rentgenowskiego od momentu jego odkrycia w 1895 r. do 1913 r., kiedy to pojawiła się właściwa lampa rentgenowska. Lampa ta, zwana lampą próżniową z gorącą katodą, wykorzystująca dzięki zjawisku termoemisji efektywne, sterowalne źródło elektronów, otworzyła nową erę w praktyce radiologicznej zarówno medycznej, jak i przemysłowej. Twórcą tej lampy był amerykański wynalazca William D. Coolidge zwany popularnie ojcem lampy rentgenowskiej.

\section{Abstract}

This article presents short outline of application of first discharge lamps (called also ion lamps or lamps with cold cathode), used to fabricating $X$ ray radiation from the moment of its discovery in 1895 to 1913 , when proper X- ray lamp appeared. This Lamp called vacuum lamp with hot cathode, due to phenomenon of thermo emission, taking advantage effective, steerable source of electrons, has opened new era in medical and also industrial radiology practice. The Author of this Lamp was American inventor William D. Coolidge called popularly the father of X-ray tube (lamp).

\section{Wstęp}

W tym roku obchodzimy 100-lecie zbudowania pierwszej właściwej lampy rentgenowskiej przez Williama D. Coolidge'a (1873-1975). Amerykański fizyk i wynalazca William D. Coolidge, wieloletni dyrektor Laboratorium Badawczego firmy General Electric w Schenectady, wniósł istotny wkład w rozwój lamp rentgenowskich (autor 83 patentów). Uznawany jest za ojca lampy rentgenowskiej, bowiem w 1913 r. zgłosił patent właściwej lampy rentgenowskiej, tj. lampy próżniowej z żarzoną katodą wolframową w miejsce stosowanych dotąd lamp wyładowczych, a więc lamp gazowanych z zimną katodą.

\section{Lampy gazowane jonowe, z zimną katodą}

Odkrycie promieni $X$ nastąpiło $w$ Niemczech, podczas badań prowadzonych przez Wilhelma C. Röntgena (1845-1923) nad promieniami katodowymi,

Dr inż. Grzegorz Jezierski - Politechnika Opolska. którymi fascynował się cały ówczesny świat naukowy. Jak obecnie wiadomo, promienie katodowe to strumień szybko poruszających się elektronów w rozrzedzonych gazach, a ich nazwa wzięła się stąd, iż miejscem ich powstawania była katoda. Lampy do ich wytwarzania to lampy gazowane, zwane też jonowymi, lub lampami z zimną katodą, a od znanego twórcy tych lamp i badacza zjawisk towarzyszących wyładowaniom elektrycznym w gazach, angielskiego fizyka Williama Crookes'a (1832-1919) zwane również lampami Crookes'a. Właśnie taką lampą dysponował Röntgen, kiedy 8 listopada 1895 r. zauważył dziwne zjawisko polegające na wydostawaniu się z lampy nowego, nieznanego promieniowania, zdolnego do przenikania przez różne materiały, w tym ludzką rękę.

Stosowane wówczas przez naukowców lampy to lampy z niewielką próżnią (ciśnienie ok. 0,1 Pa), często wypełnione jakimś gazem. Dzięki przyłożeniu wysokiego napięcia do lampy (minus do katody, plus do anody) następowała jonizacja resztek gazu w lampie i przepływ prądu - stąd lampy te nazywano również lampami jonowymi. Pod wpływem wysokiego napięcia dodatnie jony gazu, powstałe w wyniku jonizacji, ulegały przyspieszeniu między elektrodami i bombardując katodę, wyzwalały z niej elektrony. W związku z taką emisją elektronów lampy te nazywano również lampami rentgenowskimi z zimną katodą. Z kolei uwolnione z katody elektrony, ulegając przyspieszeniu pod wpływem 


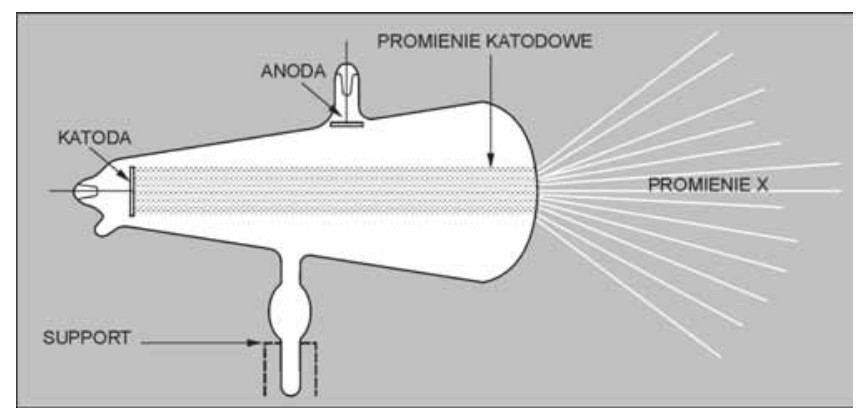

Rys. 1. Lampa wyładowcza, z którą pracował Röntgen

Fig. 1. Discharge tube used by Röntgen

przyłożonego napięcia, padały na przeciwległą ściankę bańki i emitowały w niej promienie $X$ (rys. 1).

W pierwszych lampach promieniowanie rentgenowskie było emitowane ze szklanej bańki, w miejscu, na które padały promienie katodowe (strumień szybkich elektronów), stąd też uzyskiwane obrazy rentgenowskie nie były ostre. Były nieco rozmyte, można powiedzieć, że „ognisko” tych lamp wynosiło $5 \div 8 \mathrm{~cm}$. Lampy te miały pierwotnie kształt cylindra, później pojawiły się lampy o kształcie kulistym $z$ bocznymi ramionami na wyprowadzenia elektrod.

W celu uzyskania wąskiej wiązki elektronów emitowanych przez katodę profesor Herbert Jackson (1863-1936) z King's College w Londynie zaproponował w marcu 1896 r. użycie katody o powierzchni wklęsłej zamiast dotychczasowej płaskiej. Lamp takich (zwanych fokus tube lub rurami Jacksona) używał m.in. dr John Maclntyre (1857-1928), prezydent Londyńskiego Towarzystwa Radiologicznego.

Pierwsze lampy miały kształt gruszkowaty $z$ katodą umieszczoną w węższej części. Później pod koniec 1896 r., kiedy ustalono, że kształt lampy nie ma znaczenia, zastąpiono kształt gruszkowaty wygodniejszym w produkcji kształtem sferycznym. Na elektrody stosowano głównie aluminium, aczkolwiek eksperymentowano również z innymi metalami. W czasie tych eksperymentów ustalono, że najlepszymi metalami na anody są te, które mają największą liczbę atomową. Aluminium pomimo jego niskiej liczby atomowej (27), stosowano dlatego, że pozostaje stabilne w czasie wyładowań w próżni. Wolfram (liczba atomowa 74) i uran (92) zostały użyte jedynie eksperymentalnie, natomiast preferowano platynę (78), ponieważ jest łatwiejsza do obróbki. Stąd też lampy jonowe $z$ anodą platynową były stosowane aż do pojawienia się lampy próżniowej Coolidge’a w 1913 r., w której anoda była wykonana $z$ wolframu.

W pierwszych lampach jonowych niekiedy na drodze strumienia elektronów umieszczano dodatkową trzecią elektrodę, tzw. antykatodę. Pojęcie antykatody wprowadził angielski fizyk Silvanus P. Thompson (1851-1916), przewodniczący pierwszego na świecie Towarzystwa Rentgenowskiego w Londynie, założonego w 1897 r. Terminy anoda i antykatoda niekiedy były używane zamiennie, jako że często odnosiły się one do tej samej elektrody; anoda działała bowiem jak antykatoda w pierwszych, a także późniejszych

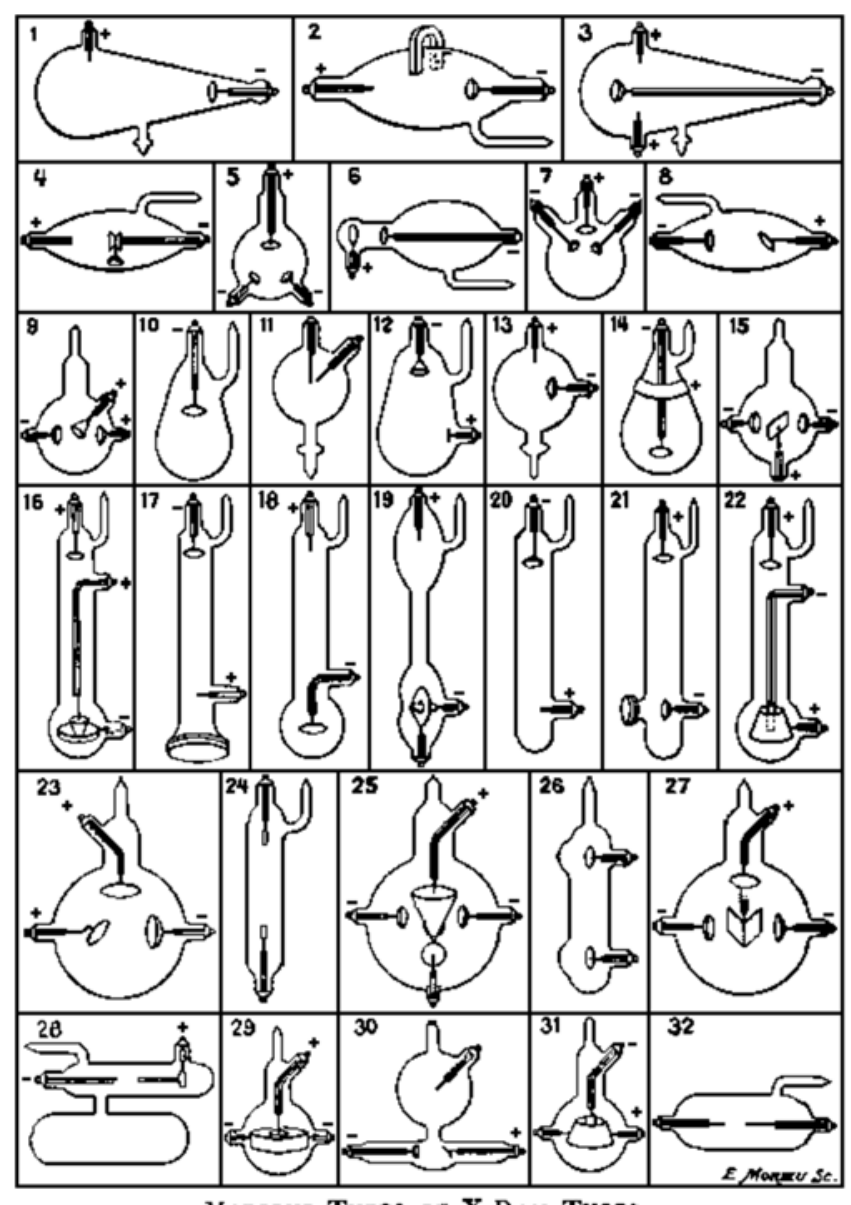

Various Types of $\mathrm{X} \cdot \mathrm{RAY}$ TUbes.

Rys. 2. Różne konstrukcje wczesnych lamp do wytwarzania promieniowania rentgenowskiego [2]. Użytkownikami lamp byli: 1 i 2 - Crookes; 3 - Seguy; 4 - Wood; 5 - Seguy; 6 - ChabaudHurmuzescu; 7 - Seguy; 8 - Thompson; 9 - Seguy; 10 - d'Arsonval; 11 - Seguy; 12 - Puluj; 13 - Seguy; 14 - d'Arsonval; 15 - Le Roux; $16 \div 18$ - Seguy; 19 - de Rufz; 20 - Crookes; $21 \div 23$ - Seguy; 24 Röntgen; 25 - Brunet-Seguy; 26, 27 - Le Roux; 28 - Colardeau; 29 - Seguy; 30 - Colardeau; 31 - Seguy; 32 - Röntgen

Fig. 2. Various forms of early cold cathode jon tubes

lampach rentgenowskich. Oczywiście antykatoda miała ten sam dodatni potencjał co anoda i była nachylona pod kątem $45^{\circ}$ do osi lampy. Lampy z trzema elektrodami były produkowane aż do lat 20. ub.w., głównie w Niemczech, mimo że eksperci $w$ tej dziedzinie nie byli zgodni co do tego, czy lampy z trzema elektrodami są lepsze niż z dwoma.

Właściwe działanie pierwszych lamp rentgenowskich (jonowych, czyli gazowanych) zależało od obecności niewielkiej ilości gazu wewnątrz lampy. Jego ilość oraz ciśnienie określały wydajność lampy. Podczas pracy takiej lampy następowała stopniowa absorpcja cząstek gazu, wskutek czego próżnia w lampie stawała się zbyt wysoka dla przepływu prądu. Wymagało to stosowania coraz wyższego napięcia; mówiło się więc, że lampa stawała się „twarda”. Jeżeli natomiast było zbyt dużo gazu wewnątrz lampy, gaz ten ulegał zjawisku fluorescencji i również nie były wytwarzane promienie X; lampa stawała się wtedy „miękka”. Stąd też, aby zapewnić zadowalającą i jednolitą pracę lamp jonowych, próżnia powinna być utrzymywana na stałym w (przybliżeniu) poziomie. Rozwiązanie regulacji 
próżni w lampach rentgenowskich (jonowych) wczesnego okresu stwarzało wiele problemów. Wykorzystywano różnorodne regulatory utrzymujące próżnię na wymaganym poziomie. Stąd też wśród pierwszych lamp rentgenowskich możemy rozróżniać lampy jonowe bez regulacji próżni oraz lampy jonowe $z$ regulacją próżni. Na „twardość” czy „miękkość” lampy oprócz samego ciśnienia gazu miały wpływ także takie czynniki jak: rodzaj gazu (powietrze, dwutlenek węgla, azot czy wodór), odległość między katodą i anodą w lampie, włączenie do lampy iskiernika, czy wreszcie gęstość prądu. Do czasu wprowadzenia regulatorów powszechna była praktyka „ustawiania lampy” (setting the tube). W tym celu operator, trzymając w prawej ręce fluoroskop, lewą rękę umieszczał pomiędzy nim a lampą rentgenowską. Po uruchomieniu ustawiał lampę za pomocą rezystora tak długo, dopóki kości jego ręki były dobrze widoczne. Ta właśnie procedura była powodem śmierci wielu pionierów radiologii.

Około 1900 r. pojawiły się lampy jonowe z samoregulacją próżni (rys. 3). Przeskok iskry pomiędzy mosiężną końcówką $P$ a ujemnym przyłączem katody $C$ powoduje uwolnienie się gazu z płytki miki i tym samym „zmiękczenie” lampy. Z kolei przyłączenie końcówki $\mathrm{D}$ do dodatniego bieguna AC powodowało absorpcję wolnego gazu przez cienki pręt metalowy umieszczony z lewej strony regulatora próżni (górna część rys. 3) i tym samym lampa ulegała „stwardnieniu”. Najbardziej znaczącym regulatorem próżni było urządzenie wprowadzone w 1897 r. przez Henry'ego L. Sayena (1875-1918) z Filadelfii w lampach zwanych lampami z samoregulacją Queen Self-Regulating X-Ray Tube.

Ponieważ pierwsze lampy rentgenowskie działały w powietrzu, ich szklane bańki były stosunkowo duże, aby nie dopuścić do przeskoku iskry pomiędzy katodą i anodą (antykatodą) na zewnątrz bańki. Lampy
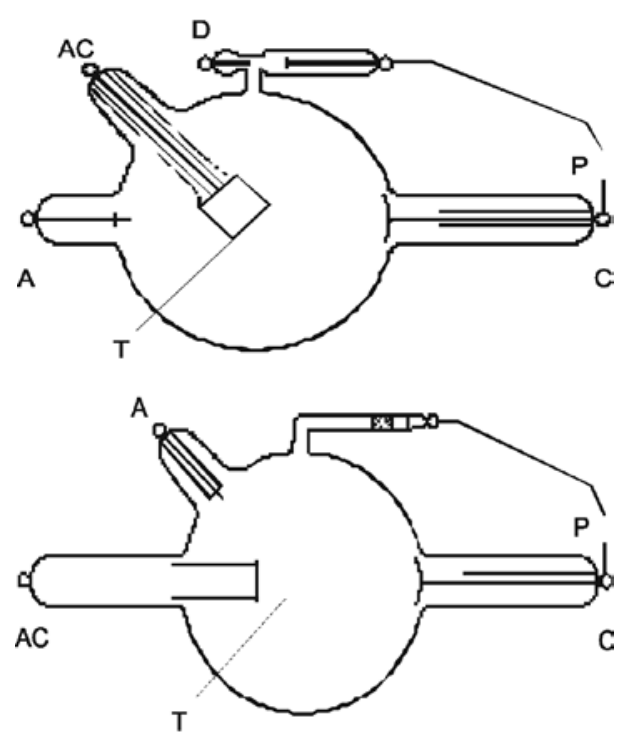

Rys. 3. Lampy jonowe $z$ samoregulacją ( $\mathrm{C}$ - katoda, $\mathrm{A}$ - anoda, AC - antykatoda, T - tarcza, P - mosiężna końcówka regulatora próżni, D - pręt metalowy w regulatorze próżni)

Fig. 3. Self-regulating tubes $(C$ - cathode, $A$ - anode, $A C$ - anticathode, $\mathrm{T}$ - target, $\mathrm{P}$ - brass pointer, $\mathrm{D}$ - metal wire) wytwarzano w różnych średnicach bańki szklanej, tj. w zakresie $110 \div 250 \mathrm{~mm}$, najczęściej jednak były to lampy 7-calowe (ok. $180 \mathrm{~mm}$ ). Lampy jonowe o mniejszej czy też większej średnicy miały swoje niedogodności. W zależności od obciążenia wysokim napięciem, które w praktyce określano długością przeskakującej iskry w powietrzu, rozróżniano następujące rodzaje lamp: A (do $20 \mathrm{~cm}$ ), B (do $30 \mathrm{~cm}$ ), C (do $40 \mathrm{~cm}$ ), D (do $50 \mathrm{~cm}$ ), $E$ (do $60 \mathrm{~cm}$ ), $F$ (do $80 \mathrm{~cm}$ ) i G (do $125 \mathrm{~cm}$ długości iskry). Niemniej jednak były to lampy nieprzekraczające napięcia 100 kV, a natężenie prądu nie przekraczało $5 \mathrm{~mA}$.

\section{Próżniowe lampy rentgenowskie}

Wszystkie opisane dotąd lampy rentgenowskie były lampami jonowymi, których działanie jest zależne od obecności pozostałości gazu w lampie. O jednej z wad lampy jonowej, tj. zmienności stopnia próżni w czasie jej działania, wspomniano już wcześniej. Inną i to istotną wadą było to, że napięcie lampy i natężenie płynącego przez nią prądu są współzależne. Przyczyną, dla której jest to istotne, jest fakt, że penetracja promieni Röntgena zależy od napięcia, a natężenie promieniowania od natężenia prądu. W lampach jonowych redukcja ciśnienia gazu („utwardzenie” lampy) prowadzi do wzrostu napięcia i stąd generowania bardziej przenikliwych promieni Röntgena. Ale ponieważ jest mniej gazu w lampie, natężenie prądu spada i natężenie wiązki rentgenowskiej również się zmniejsza.

Wspomniany problem sterowania pracą lampy rentgenowskiej został rozwiązany w 1911 r. przez fizyka polskiego pochodzenia Juliusza Edgara Lilienfelda (1881-1963) w całkiem prosty sposób. Otóż wykorzystał on do wytwarzania strumienia elektronów zjawisko termoemisji, czyli emisji elektronów z żarzącej się spirali metalowego drutu. Mechanizm termoemisji odkryty w 1885 r. przez Thomasa A. Edisona (1847-1931) wyjaśnił angielski fizyk Owen W. Richardson (1879-1959) wykazując, że ciała rozgrzane w próżni do wysokiej temperatury emitują elektrony. Lilienfeld, budując wiele różnych lamp rentgenowskich i patentując je, popadł nawet w konflikt z innym amerykańskim wynalazcą Williamem D. Coolidgem. W 1910r. Coolidge wynalazł giętkie włókno wolframowe, które żarzyło się w podwyższonych temperaturach. Początkowo znalazło ono zastosowanie w produkcji żarówek elektrycznych. W przeciwieństwie do lampy Lilienfelda, która miała zimną katodę i dodatkowo żarzące się włókno do wytwarzania elektronów, Coolidge zbudował w 1913 r. lampę, w której włókno wolframu stanowiące katodę samo emitowało elektrony - stąd też lampy te zwano w początkowym okresie lampami z gorącą katodą (hot cathode) - patent 1.203.495. Ta nowa lampa $z$ dość wysoką próżnią (ciśnienie rzędu $10^{-4} \mathrm{~Pa}$ ) wytwarzała znacznie więcej promieniowania rentgenowskiego w porównaniu z dotychczasowymi 
lampami gazowanymi, a przede wszystkim była sterowalna - można było sterować natężeniem prądu niezależnie od wysokiego napięcia. Trzeba więc było czekać niecałe dwadzieścia lat, aby w 1913 r. za sprawą Coolidge'a pojawiła się właściwa lampa rentgenowska. Przy okazji warto podkreślić, że ten „ojciec lampy rentgenowskiej”, twórca 83 patentów dotyczących lamp rentgenowskich, a więc testujący ich działanie i pracę, dożył w otoczeniu promieniowania jonizującego (rentgenowskiego) sędziwego wieku 102 lat! Przez wiele lat piastował stanowisko dyrektora Laboratorium Badawczego w firmie General Electric. Lampa z gorącą katodą, tj. lampa Coolidge’a otworzyła nową erę w praktyce radiologicznej, a dla firmy General Electric w Schenectady stała się wielkim biznesem.

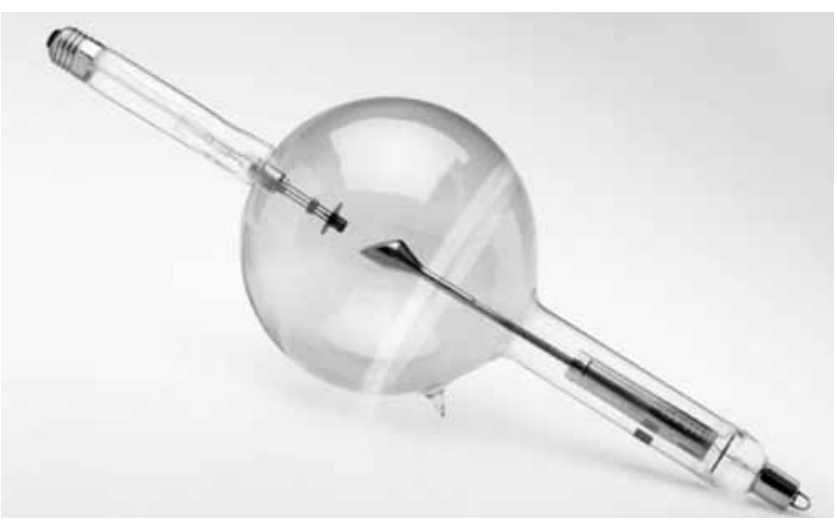

Rys. 4. Lampa Coolidge'a

Fig. 4. Early Coolidge tube

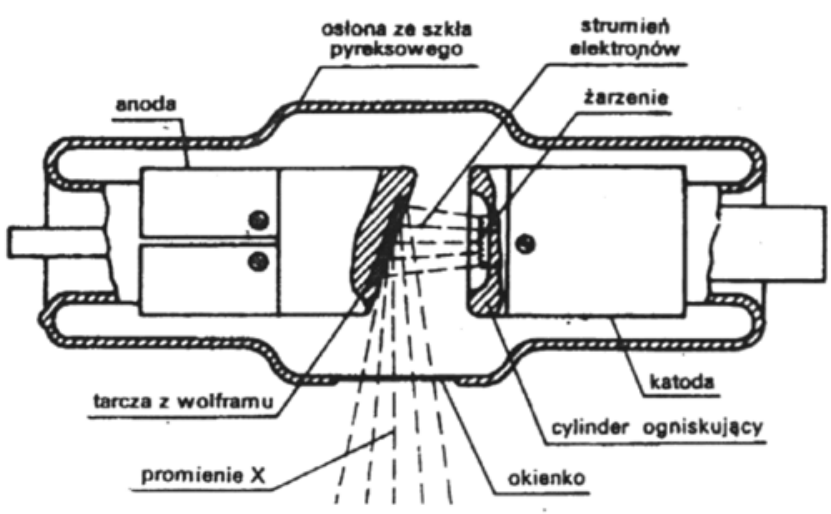

Rys. 5. Przekrój współczesnej lampy rentgenowskiej

Fig. 5. Cross section of modern X-ray tube

W tablicy I przedstawiono porównanie charakterystycznych różnic pomiędzy lampami jonowymi (wczesne lampy) i próżniowymi (współczesne lampy).

Dla przypomnienia warto przedstawić ogólny widok lampy Coolidge’a (rys. 4) oraz przekrój współczesnej konstrukcji lampy rentgenowskiej (rys. 5). Pierwsze lampy Coolidge'a to duże szklane bańki o średnicy zwykle ok. $18 \mathrm{~cm} \mathrm{z} \mathrm{dwoma} \mathrm{bocznymi} \mathrm{ramionami} \mathrm{-} \mathrm{całość}$ o długości ok. pół metra. Na bazie konstrukcji lampy Coolidge'a wprowadzano kolejne liczne rozwiązania udoskonalające lampy rentgenowskie zarówno pod kątem lepszej ostrości obrazu, wydajności emitowanego promieniowania rentgenowskiego, jak i zabezpieczenia
Tablica I. Porównanie lamp rentgenowskich

Table I. Comparison of early and modern X-ray tubes

\begin{tabular}{|l|l|}
\hline Wczesne lampy & Współczesne lampy \\
\hline wypełnione gazem & próżniowe \\
\hline $\begin{array}{l}\text { ciśnienie: } 0,1 \mathrm{~Pa} \div 005 \mathrm{~Pa} \\
\left(10^{-3} \div 5 \cdot 10^{-5} \text { tor }\right)\end{array}$ & $\begin{array}{l}\text { ciśnienie: } \sim 10^{-4} \mathrm{~Pa} \\
\left(\sim 10^{-6} \text { tor }\right)\end{array}$ \\
\hline $\begin{array}{l}\text { niestabilne źródło } \\
\text { elektronów }\end{array}$ & $\begin{array}{l}\text { sterowalne źródło } \\
\text { elektronów }\end{array}$ \\
\hline $\begin{array}{l}\text { jako tarczę wykorzystywa- } \\
\text { no ściankę lampy }\end{array}$ & $\begin{array}{l}\text { stosuje się małą metalową } \\
\text { tarczę }\end{array}$ \\
\hline $\begin{array}{l}\text { brak układu do ogniskowa- } \\
\text { nia wiązki elektronów }\end{array}$ & $\begin{array}{l}\text { układ ogniskujący wiązkę } \\
\text { elektronów }\end{array}$ \\
\hline $\begin{array}{l}\text { kształt katody nie jest } \\
\text { krytyczny }\end{array}$ & katoda w postaci żarnika \\
\hline $\begin{array}{l}\text { małe moce lamp - nie- } \\
\text { wielka ilość wydzielanego } \\
\text { ciepła }\end{array}$ & $\begin{array}{l}\text { znaczne moce - duże ilości } \\
\text { wydzielanego ciepła }\end{array}$ \\
\hline
\end{tabular}

przed niepożądanym promieniowaniem ubocznym. I tak np. w 1918 r. uzyskano znaczne zmniejszenie ogniska w lampie, wykorzystując tzw. zasadę ogniska liniowego, opatentowaną przez Ferdynanda Ottomara Roberta Goetze (1850-1916). Polegała ona na zmianie konstrukcji żarnika, tj. zamiast dotychczas stosowanej okrągłej spirali zastosowano spiralę liniową, co w powiązaniu z odpowiednim umieszczeniem jej względem pochylonej anody dawało małe ognisko optyczne, chociaż ognisko rzeczywiste pozostawało duże. Z czasem coraz więcej lamp rentgenowskich wyposażano w dwa ogniska: większe i mniejsze. Większego ogniska używano, gdy pracowano przy większych obciążeniach na lampie, a mniejsze ognisko stosowano wtedy, kiedy trzeba było uzyskać ostrzejszy obraz.

Bardzo istotnym problemem było także stworzenie lepszego systemu ochronnego przed porażeniem wysokim napięciem personelu obsługującego aparaturę rentgenowską. Należy bowiem pamiętać, że w pierwszych latach ubiegłego wieku gołe szklane lampy Coolidge'a pracowały w powietrzu, bez żadnych kołpaków czy głowic. W 1919 r. Harry F. Waite (1874-1846) skonstruował aparaturę z lampą zanurzoną w oleju, który zapewniał lepszą izolację elektryczną oraz chłodzenie lampy niż samo powietrze. Takie rozwiązanie pozwalało na wyprodukowanie bardziej bezpiecznego, a zarazem mniejszego aparatu rentgenowskiego.

Kolejnym wyzwaniem dla firm produkujących lampy rentgenowskie było uzyskanie w lampie dużego prądu anodowego, rzędu setek mA, co pozwalałoby na skrócenie czasu ekspozycji, a także wyższego napięcia

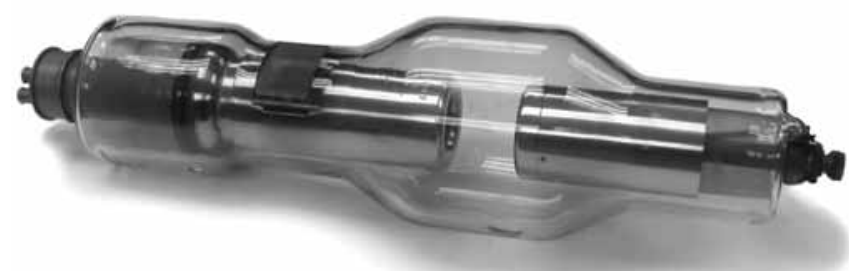

Rys. 6. Lampa rtg SRT-2 firmy General Electric [3]

Fig. 6. General Electric SRT-2 tube 


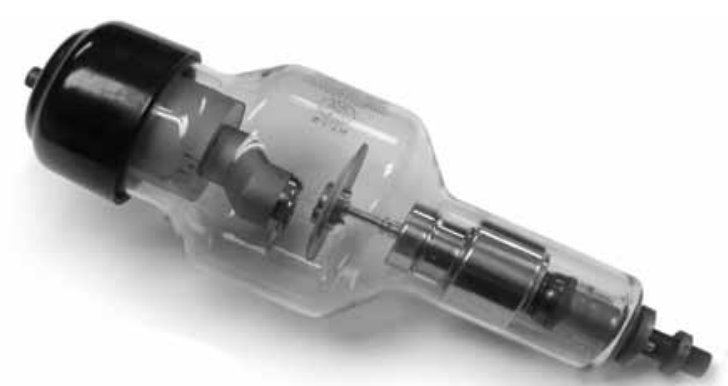

Rys. 7. Lampa z anodą wirującą RT-1-2 firmy General Electric [3] Fig. 7. General Electric RT-1-2 rotating anode tube przyspieszającego, co umożliwiłoby z kolei prześwietlanie materiałów o większych grubościach. Zwiększenie natężenia prądu anodowego skutkuje większym obciążeniem cieplnym ogniska w tarczy anody. Stąd też w miejsce stałej anody opracowano i wdrożono komercyjnie w 1929 r. lampę z anodą wirującą - była to lampa zwana Rotalix firmy Philips. Sama idea anody wirującej znana była dużo wcześniej, bo już w 1897 r. zaproponował ją fizyk z Uniwersytetu Hopkinsa Robert Wood (1868-1955). I aczkolwiek pierwszą konstrukcję lampy z anodą wirującą opracował William Coolidge

Tablica II. Podział lamp rentgenowskich ze względu na istotne cechy konstrukcyjne

Table II. Classification of X-ray tubes

\begin{tabular}{|c|}
\hline ędu na konstruk \\
\hline $\begin{array}{l}\text { - lampy zamknięte (nierozbieralne) } \\
\text { - lampy otwarte (rozbieralne) }\end{array}$ \\
\hline Ze względu na rodzaj obudowy lampy rozróżnia się: \\
\hline $\begin{array}{l}\text { - lampy nieosłonięte (gołe) } \\
\text { - lampy obudowane }\end{array}$ \\
\hline Ze względu na rodzaj materiału bańki rozróżnia się: \\
\hline $\begin{array}{l}\text { - lampy szklane } \\
\text { - lampy metalowo-szklane } \\
\text { - lampy metalowo-ceramiczne }\end{array}$ \\
\hline Ze względu na charakter pracy rozróżnia się: \\
\hline $\begin{array}{l}\text { - lampy do pracy ciągłej } \\
\text { - lampy do pracy okresowej } \\
\text { - lampy do pracy impulsowej }\end{array}$ \\
\hline Ze względu na rodzaj katody rozróżnia się: \\
\hline $\begin{array}{l}\text { - lampy z katodą w postaci żarnika z włókna wolframowego } \\
\text { - lampy z katodą zasobnikową (impregnowaną) } \\
\text { - lampy z katodą z LaB } \\
\text { - lampy z katodą Schottky’ego } \\
\text { - lampy z katodą zimną } \\
\text { - lampy z katodą wykonaną z nanorurek węglowych CNT } \\
\text { - lampy z fotokatodą (lampy rentgenowskie wzbudzane } \\
\text { światłem) }\end{array}$ \\
\hline Ze względu na liczbę anod rozróżnia się: \\
\hline $\begin{array}{l}\text { - lampy z pojedynczą anodą } \\
\text { - lampy z podwójną anodą (dual)/z bliźniaczą anodą (twin) } \\
\text { - lampy z wieloma anodami }\end{array}$ \\
\hline Ze względu na konstrukcję anody: \\
\hline $\begin{array}{l}\text { - lampy z anodą pełną } \\
\text { - lampy z anodą drążoną }\end{array}$ \\
\hline Ze względu na stan ruchu anody rozróżnia się: \\
\hline $\begin{array}{l}\text { - lampy z anodą stałą (nieruchomą); anoda zwykła, anoda } \\
\text { wydłużona } \\
\text { - lampy z anodą wirującą (tarcza lub cylinder) }\end{array}$ \\
\hline Ze względu na materiał anody rozróżnia się: \\
\hline $\begin{array}{l}\text { - lampy z anodą miedzianą } \\
\text { - lampy z anodą wolframową } \\
\text { - lampy z anodą molibdenową } \\
\text { - lampy z anodą z RT, RTM, RTMC, TZM }\end{array}$ \\
\hline
\end{tabular}

Ze względu na stan fizyczny materiału tarczowego rozróżnia się:

- tarczę w postaci ciała stałego

- tarczę w postaci cieczy

- tarczę w postaci gazu

Ze względu na materiał tarczy anody rozróżnia się:

$\mathrm{Ag}, \mathrm{Al}, \mathrm{Au}, \mathrm{Ca}, \mathrm{Ce}, \mathrm{Co}, \mathrm{Cr}, \mathrm{Cu}, \mathrm{Fe}, \mathrm{Gd}, \mathrm{Ge}, \mathrm{La}, \mathrm{Mg}, \mathrm{Mn}$, $\mathrm{Mo}, \mathrm{Ni}, \mathrm{Nb}, \mathrm{Pd}, \mathrm{Pt}, \mathrm{Re}, \mathrm{Rh}, \mathrm{Sc}, \mathrm{Si}, \mathrm{Ta}, \mathrm{Th}, \mathrm{Ti}, \mathrm{Tm}, \mathrm{V}, \mathrm{Y}$, $\mathrm{Zr}, \mathrm{W}$, tarcza diamentowa, tarcze tlenkowe

Ze względu na kąt nachylenia tarczy stałej rozróżnia się:

$0^{\circ}, 5^{\circ}, 6^{\circ}, 6,5^{\circ}, 7^{\circ}, 8^{\circ}, 10^{\circ}, 11^{\circ}, 12^{\circ}, 12,5^{\circ}, 13^{\circ}, 13,5^{\circ}, 14^{\circ}$, $14,5^{\circ}, 15^{\circ}, 16^{\circ}, 17^{\circ}, 17,5^{\circ}, 18^{\circ}, 19^{\circ}, 20^{\circ}, 21^{\circ}, 22^{\circ}, 23^{\circ}$, $24^{\circ}, 24,5^{\circ}, 25^{\circ}, 26^{\circ}, 27^{\circ}, 30^{\circ}, 32^{\circ}, 33^{\circ}, 35^{\circ}, 40^{\circ}, 42^{\circ}, 45^{\circ}$, $55^{\circ}, 67,5^{\circ}, 78^{\circ}, 90^{\circ}$ (anoda transmisyjna)

Ze względu na zasilanie lampy rozróżnia się:

- lampy dwubiegunowe

- lampy jednobiegunowe (uziemiona anoda lub uziemiona katoda)

Ze względu na chłodzenie anody rozróżnia się:

- lampy z chłodzeniem powietrznym

- lampy z chłodzeniem gazowym

- lampy z chłodzeniem wodnym

- lampy z chłodzeniem olejowym

Ze względu na położenie okienka rozróżnia się:

- lampy z wiązką boczną

- lampy z wiązką wzdłużną

Ze względu na kształt wiązki promieniowania rozróżnia się:

- lampy z wiązką kierunkową (stożkową)

- lampy z wiązką panoramiczną

- lampy z wiązką wachlarzową

- lampy z wiązką punktową

Ze względu na liczbę okienek rozróżnia się:

- lampy z jednym okienkiem

- lampy z dwoma okienkami

- lampy z trzema okienkami

- lampy z czterema okienkami

R - Rhenium, T - Tungsten, M - Molybdenum, C - Graphite, TZM - stop $\operatorname{Ti}(0,5 \%), \operatorname{Zr}(0,08 \%)$ i Mo $(99,2-00,5 \%)$, 
w 1915 r., to komercyjne wdrożenie tego typu lampy przypisuje się Albertowi Bouwersowi (1893-1972) z firmy Philips - była to anoda wirująca w formie miedzianego cylindra z powierzchnią czołową pokrytą wolframem. Konstrukcję tej anody udoskonalił następnie Alfred Ungelenk (1890-1978), zamieniając cylinder na tarczę o pochylonej płaszczyźnie, czyli tzw. dysk anodowy.

Lampa $z$ anodą wirującą konstrukcyjnie jest bardziej złożona niż lampa z anodą stałą, podstawowym bowiem problemem jest w niej odprowadzenie ciepła.
Lampy z anodą wirującą mają podstawowe zastosowanie w medycynie, w tym również we współczesnych tomografach medycznych.

Pomimo swej prostoty, jeśli chodzi o fizyczne działanie ww. lampy rentgenowskiej (z punktu widzenia elektrycznego jest to po prostu dioda lub trioda), to ze względu na szerokie zastosowanie promieniowania rentgenowskiego w różnych obszarach działalności człowieka istnieje duża rozmaitość współczesnych lamp rentgenowskich, co przedstawiono w tablicy II.

\title{
Podsumowanie
}

Aczkolwiek określenie lampa rentgenowska jest używane w literaturze od początku odkrycia promieniowania $X$, to właściwa lampa rentgenowska pojawiła się dopiero w 1913 r. a więc ponad 18 lat od tego odkrycia. Trzeba było poczekać na wynalezienie giętkiego włókna wolframowego i wykorzystanie go w zjawisku termoemisji, aby pojawiła się gorąca katoda, emitująca w sposób sterowalny emisją elektronów. Technika ta mimo wielu udoskonaleń i różnych rozwiązań konstrukcyjnych samej lampy rentgenowskiej pozostaje do dziś niezmienna w konstrukcji większości lamp rentgenowskich na świecie.

\section{Literatura}

[1] Jezierski Grzegorz : Lampy rentgenowskie wczoraj i dziś, materiały niepublikowane, 2013.

[3] http://www.orau.org/ptp/collection/xraytubescoolidge/xraytubescoolidge.htm

\section{Badania nieniszczące kolejowych zestawów kołowych w trakcie ich eksploatacji. Praktyka warsztatowa w Wagon Service Ostróda}

\author{
Non-destructive testing of railway wheelsets during service. \\ Workshop practice in Wagon Service Ostróda
}

\footnotetext{
W referacie przedstawiono obszary stosowania badań nieniszczących w kolejnictwie, metody badań stosowane podczas rewizji zestawów kołowych w eksploatacji, ich cel i sposoby oceny wyników. Omówiono wymagania stawiane kolejowym zakładom naprawczym wykonującym NDT dotyczące: personelu badającego, wyposażenia badawczego, oraz organizacji i nadzoru nad badaniami. Wyspecyfikowane zostały normatywne dokumenty polskie i europejskie zawierające wymagania techniczne obowiązujące przy realizacji procesów badawczych części i podzespołów kolejowych. Omówiono także wybrane zagadnienia technologiczne z zakresu procesów badawczych i wyposażenie niezbędnego do ich realizacji, oraz sposób zapis przebiegu i wyników badania oraz ich archiwizację.
}

In this article the area of applying non-destructive tests in railway maintenance sector was presented, as well as methods of tests used during inspection of wheelsets in operation, their goal and methods of results evaluation. It was discussed requirements for railway repair institutions that use NDT specially for personnel, equipment, organization and supervision of tests. It was listed polish and international standards that contain technical requirements for realisation of NDT in railway maintenance sector. It was also discussed selected technological problems in the field of test processes and equipment necessary to implement them, and possibilities of test results recording and its archiving.

Referat wygłoszono podczas 42. KKBN w Kołobrzegu 